\title{
A Novel Method to Overcome Coat-Imposed Seed Dormancy in Lupinus albus L. and Trifolium pratense $\mathbf{L}$.
}

\author{
Iskender Tiryaki ${ }^{1}$ and Mustafa Topu ${ }^{2}$ \\ ${ }^{1}$ Department of Agricultural Biotechnology, Faculty of Agriculture, Canakkale Onsekiz Mart University, \\ Terzioglu Campus, 17020 Canakkale, Turkey \\ ${ }^{2}$ Kahramanmaras Anadolu Oğretmen Lisesi, 46100 Kahramanmaras, Turkey
}

Correspondence should be addressed to Iskender Tiryaki; itiryaki@comu.edu.tr

Received 7 May 2014; Revised 18 July 2014; Accepted 19 July 2014; Published 3 August 2014

Academic Editor: Bhagirath S. Chauhan

Copyright (C) 2014 I. Tiryaki and M. Topu. This is an open access article distributed under the Creative Commons Attribution License, which permits unrestricted use, distribution, and reproduction in any medium, provided the original work is properly cited.

We have developed a novel method to overcome coat-imposed seed dormancy in legume plants. Seeds of Lupinus albus L. and Trifolium pratense $\mathrm{L}$. were stored in a freezer at $-80^{\circ} \mathrm{C}$ for a period of time and then immediately treated with or without hot water at $90^{\circ} \mathrm{C}$ for 5 seconds. Germination tests were carried out in darkness at $20 \pm 1.0^{\circ} \mathrm{C}$ with four replications in a completely randomized design. Final germination percentage (FGP), germination rate, and synchrony of seeds were evaluated. The results showed that new approach of freeze-thaw scarification provided high percentage of germinations in white lupin (84.16\%) and red clover (74.50\%) seeds while control seeds had FGPs of $3.3 \%$ and $26.0 \%$, respectively. The immediate thawing of frozen seeds in hot water for 5 seconds was found not only an effective and reliable but also the quickest seed treatment method to prevail against coat-imposed seed dormancy in legume species and may become operationally applicable to other plant species.

\section{Introduction}

Dormant seeds which are unable to germinate under favourable environmental conditions remain hard and ungerminated for a period of time [1]. However, the mechanisms of seed dormancy are still to be elucidated and, therefore, the classification of the different types of dormancy is entirely based on its expression under various conditions [1-4]. The coat-imposed seed dormancy (hardseededness) is due to either the impermeability of the coat to water and/or gases, the mechanical prevention of radicle extension, or the seed coat preventing inhibitory substances from leaving the embryo or by supplying inhibitors to the embryo $[5,6]$. Water impermeable testa prevents the entry of water into seed and seed remains hard even when appropriate moisture and temperature conditions are provided [5]. The presence of a hard and impermeable seed coat is regarded as a widespread cause of seed dormancy in several important legume species such as in lentil [7], faba bean [8], common bean [9], soybean $[10,11]$, cowpea [12], common vetch [13], alfalfa and clover [14-16], and in some other important plant families such as
Geraniaceae (Pelargonium sp.) [17], Oleaceae (Fraxinus sp.) [18], and Malvaceae (Abelmoschus sp.) [19].

Although hard seed coat improves the survival of seeds in the soil especially in adverse environmental conditions and helps to avoid extinction of species in nature, it may prevent use of plant cultivars or wild-type relatives for agricultural or breeding purposes [20,21]. There are, however, several factors or events that reduce or partially overcome coat-imposed seed dormancy in which the seed coat is usually disrupted by using mechanical or chemical applications such as nicking or sandpaper, acid scarification, or heat treatments such as boiling water soak $[13,22,23]$. The objective of the present study was to develop an alternative and effective as well as reliable seed treatment method to defeat coat-imposed seed dormancy in Fabaceae.

\section{Material and Methods}

2.1. Material. Lupinus albus L. (white lupin) and Trifolium pratense L. (red clover) seeds were used in this study. White lupin seeds were collected from natural flora of Aksu 
$\left(37^{\circ} 30^{\prime} 33^{\prime \prime} \mathrm{N} 36^{\circ} 53^{\prime} 43^{\prime \prime} \mathrm{E}\right)$, Kahramanmaras, Turkey, and red clover seeds collected from natural flora of Ordu, Turkey, were generously provided by Dr. Asci et al. [16]. White lupin and red clover seeds were 5 and 26 months old, respectively. Seed moisture contents of white lupin and red clover seeds were determined as $11.1 \%$ and $10.7 \%$, respectively, based on dried sample mass by using moisture analyzer (MX-50, A\&D Company, Limited, Tokyo, Japan) at $200^{\circ} \mathrm{C}$ as per the manufacturer's instructions.

\subsection{Methods}

2.2.1. Seed Treatments. White lupin seeds were stored in a freezer at $-80^{\circ} \mathrm{C}$ for $0,1,2,4$, or 7 days in plastic zip lack bags and then immediately treated with or without hot water $(\mathrm{HW})$ at $90^{\circ} \mathrm{C}$ for 5 seconds. Based on the results of lupin experiment, redclover seeds were stored in a freezer at $-80^{\circ} \mathrm{C}$ for 0 or 1 day and then were immediately treated with or without $\mathrm{HW}$ at $90^{\circ} \mathrm{C}$ for 5 seconds.

2.2.2. Germination Test. Germination tests were carried out in darkness in a temperature-controlled incubator held at $20 \pm 1.0^{\circ} \mathrm{C}$. Seeds were placed on two layers of filter paper moistened with $3 \mathrm{~mL}$ of deionized water in covered $5.5 \mathrm{~cm}$ glass petri dishes. Four replications of 40 and 50 seeds were arranged in a completely randomized design for lupin and red clover seeds, respectively. Shortage of lupin seeds forced us to use 40 seeds per replication rather than 50 seeds as we used in red clover. To be able to calculate rate and spread of germination, the seeds germinated (radicle visible) were removed from petri dishes daily until the numbers stabilized (for 7 days). From the total number of seeds germinated, final germination percentage (FGP), and its angular transformation (arcsine $\sqrt{\mathrm{FGP}}$ ), days to $50 \%$ of FGP and days between $10 \%$ and $90 \%$ of FGP were calculated [24]. Time to $50 \%$ of FGP $\left(G_{50}\right)$ is an inverse measure of germination rate, while time between $10 \%$ and $90 \%$ of FGP $\left(\mathrm{G}_{10-90}\right)$ is considered to be an estimate of the spread of germination, the inverse of germination synchrony.

2.2.3. Data Analysis. Data were subjected to analysis of variance using SAS statistical software [25], and mean separation was performed by Fisher's least significant difference (LSD) test if $F$ test was significant at $P<0.05$.

\section{Results}

The preexperimental trials, including boiling water, acid scarification, storage of seeds in a deep freezer at $-20^{\circ} \mathrm{C}$ and at $-80^{\circ} \mathrm{C}$, and immersing seeds in liquid nitrogen, indicated that white lupin seeds stored in deep freezer at $-80^{\circ} \mathrm{C}$ or treated with $\mathrm{HW}$ had promising results compared to the other methods tested (data not shown). Therefore, we have set a new experiment to evaluate storage time of seeds in deep freezer at $-80^{\circ} \mathrm{C}$ for $0,1,2,4$, or 7 days in plastic zip lack bags and treatment of those seeds with or without $\mathrm{HW}$ at $90^{\circ} \mathrm{C}$ for 5 seconds.

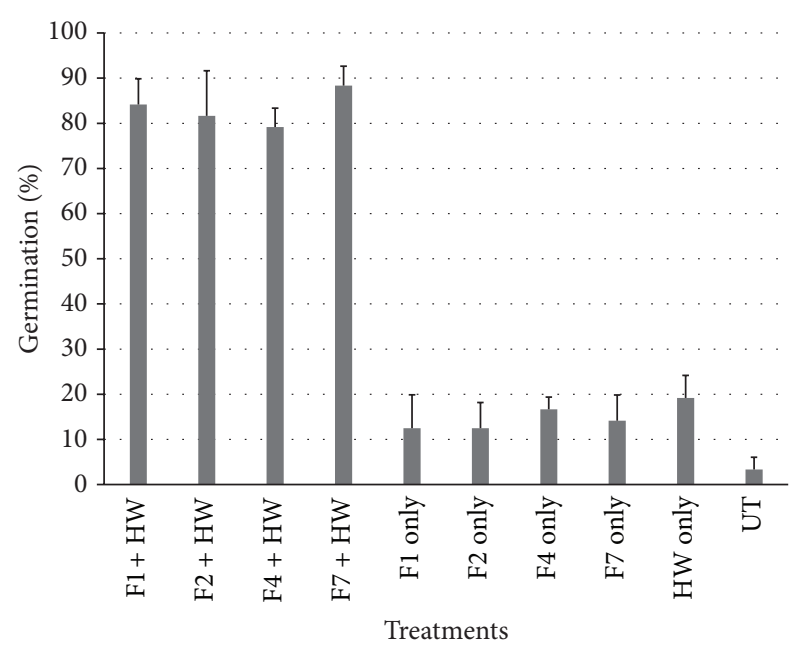

I $\mathrm{LSD}_{0.05}$

FIGURE 1: The effects of various treatments on final germination percentage of Lupinus albus L. seed germination. HW: hot water; F1-7: storage of seed in deep freezer for 1-7 day(s); UT: untreated control seed. Error bars indicate standard deviation $(n=4)$.

TABLE 1: Angular transformation [degree] of final germination percentage (FGP), days to $50 \%$ of FGP $\left(\mathrm{G}_{50}\right)$, and days between $10 \%$ and $90 \%$ germination $\left(\mathrm{G}_{10-90}\right)$ of Lupinus albus $\mathrm{L}$. seed germination at $20^{\circ} \mathrm{C}$ following various treatments.

\begin{tabular}{lccc}
\hline Treatments & $\begin{array}{c}\text { FGP } \\
\text { [Degree] }\end{array}$ & $\begin{array}{c}\mathrm{G}_{50} \\
\text { (Days) }\end{array}$ & $\begin{array}{c}\mathrm{G}_{10-90} \\
\text { (Days) }\end{array}$ \\
\hline F1 only & {$[19.83]$} & 5.04 & 3.38 \\
F2 only & {$[20.36]$} & 5.31 & 2.36 \\
F4 only & {$[24.09]$} & 4.00 & 3.82 \\
F7 only & {$[21.84]$} & 4.00 & 4.03 \\
F1 + HW & {$[66.85]$} & 3.58 & 2.31 \\
F2 + HW & {$[65.31]$} & 3.68 & 3.29 \\
F4 + HW & {$[62.80]$} & 3.46 & 3.41 \\
F7 + HW & {$[70.18]$} & 3.44 & 2.69 \\
HW only & {$[25.29]$} & 3.10 & 2.82 \\
UT & {$[8.82]$} & 1.50 & 1.05 \\
\hline LSD & {$[7.29]$} & 0.90 & 1.34 \\
Significance & $* *$ & $* *$ & $* *$ \\
\hline
\end{tabular}

${ }^{* *}$ Significant at $P<0.01$. HW: hot water; F1-7: storage of seeds in deep freezer for 1-7 day(s); UT: untreated control seed.

The FGPs of this experiment were presented in Figure 1. Speed and span of germination and angular transformation of FGP were given in Table 1. The results revealed that all seed treatments tested significantly improved FGP of white lupin compared to untreated (UT) control seeds. The results also indicated that storage of seeds in deep freezer for any given time or seeds treated with HW only had significant effect on germination parameters in comparison to UT control seeds which had an FGP of 3.33\%. Significant differences were also determined between storage of seeds in deep freezer and treatment of seeds with HW only. Seeds stored in deep freezer only had lower FGPs than seeds treated with 
TABLE 2: Angular transformation [degree] of final germination percentage (FGP), days to $50 \%$ of FGP $\left(\mathrm{G}_{50}\right)$, and days between $10 \%$ and $90 \%$ germination $\left(\mathrm{G}_{10-90}\right)$ of Trifolium pratense $\mathrm{L}$. seed germination at $20^{\circ} \mathrm{C}$ following various treatments.

\begin{tabular}{lccc}
\hline Treatments & $\begin{array}{c}\text { FGP } \\
\text { [Degree] }\end{array}$ & $\begin{array}{c}\mathrm{G}_{50} \\
\text { (Days) }\end{array}$ & $\begin{array}{c}\mathrm{G}_{10-90} \\
\text { (Days) }\end{array}$ \\
\hline F1 + HW & {$[59.72]$} & 1.61 & 2.44 \\
F1 only & {$[37.72]$} & 2.51 & 3.70 \\
HW only & {$[34.10]$} & 1.63 & 3.08 \\
UT & {$[30.50]$} & 1.94 & 2.55 \\
\hline LSD $_{0.05}$ & {$[5.16]$} & 0.58 & 1.50 \\
Significance & $* *$ & $*$ & ns
\end{tabular}

${ }^{*, * *}$ Significant at $P<0.05$ and $P<0.01$, respectively. ns: not significant at $P<0.05$; HW: hot water; F1: storage of seeds in deep freezer for 1 day; UT: untreated control seed.

HW per se (Table 1). Although not significantly different, extending the storage time in deep freezer led to a progressive increase in FGP (Figure 1). The highest FGPs $(88.33 \%$ and $84.16 \%$ ) were, however, obtained from seeds treated with HW following storage of seeds in deep freezer for 1 or 7 days, respectively. Germination rate and synchrony (higher $\mathrm{G}_{50}$ and $G_{10-90}$ ) were worsened when seeds were stored in deep freezer only (F1-7) compared to UT control seeds and F1-7 + HW combination (Table 1). Seeds treated with HW only had faster $\left(G_{50}=3.1\right.$ days $)$ germination rate than seeds of the other treatments while the lowest rate of germination $\left(\mathrm{G}_{50}\right.$ $=1.5$ days) was obtained from UT control seeds. Speed of germination was the slowest $\left(G_{50}=5.04\right.$ days $)$ for seeds stored in deep freezer for 1 day only (Table 1 ).

Seeds stored in deep freezer for 7 days resulted in the least synchronous germination $\left(\mathrm{G}_{10-90}=4.03\right.$ days $)$ while the most uniform germination $\left(\mathrm{G}_{10-90}=1.05\right.$ days $)$ was obtained from UT control seeds (Table 1). The F1 + HW treatment had the lowest number of days for germination synchrony $\left(\mathrm{G}_{10-90}=\right.$ 2.31 days) compared to the other treatments tested (Table 1 ). Considering storage time and its effect on germination parameters, immediate immersing of seeds in $\mathrm{HW}$ at $90^{\circ} \mathrm{C}$ for 5 seconds following storage in a deep freezer at $-80^{\circ} \mathrm{C}$ for one day $(\mathrm{F} 1+\mathrm{HW})$ was not only an effective but also the quickest seed treatment method to defeat coat-imposed seed dormancy in white lupin compared to the other treatments. The effectiveness of F1 + HW treatment was further tested on red clover seeds.

The treatment of F1 + HW on red clover seeds significantly enhanced FGP and rate of germination while no beneficial effect was determined on span of germination compared to UT control seeds (Table 2 and Figure 1). The highest FGP (74.5\%) was obtained from seeds treated with F1 + HW method compared to UT control seeds which had an FGP of $26 \%$ (Figure 2). The results also indicated that storage of red clover seeds in deep freezer at $-80^{\circ} \mathrm{C}$ for 1 day ( $\mathrm{F} 1$ only) was more effective in defeating coatimposed seed dormancy (37.5\%) than treatment of seeds with HW only (31.5\%) (Figure 2). All the seed treatments worsened germination rate and synchrony (higher $G_{50}$ and $\left.\mathrm{G}_{10-90}\right)$, except $\mathrm{F} 1+\mathrm{HW}\left(\mathrm{G}_{50}=1.61\right.$ days $)$ which resulted

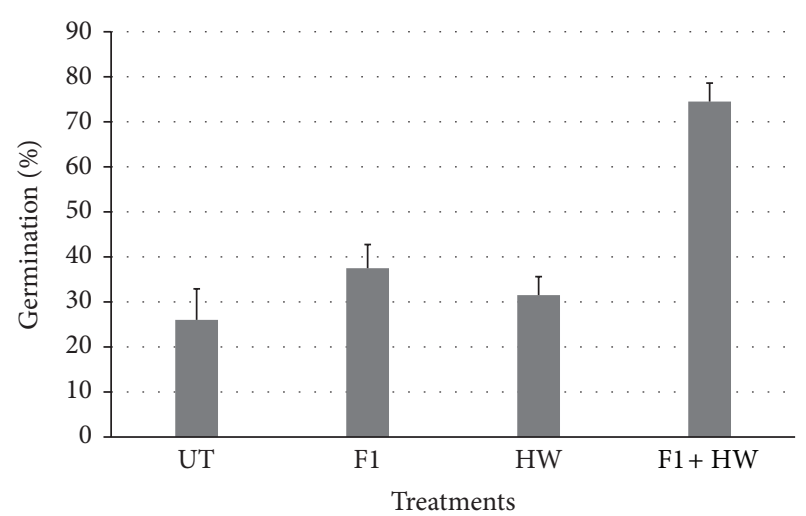

I $\operatorname{LSD}_{0.05}$

FIGURE 2: The effects of various treatments on final germination percentage of Trifolium pratense L. seed germination. HW: hot water; F1: storage of seed in deep freezer for 1 day; UT: untreated control seed. Error bars indicate standard deviation $(n=4)$.

in slight decrease on germination rate compared to the rest of the treatments tested, including UT control seeds $\left(\mathrm{G}_{50}=\right.$ 1.94 days); however, this improvement was not significant (Table 2). The treatments showed no significant effect on the germination synchrony (Table 2).

\section{Discussion}

Fabaceae comprise one of the most important agricultural taxa worldwide, providing a major source of protein for mankind as well as animals [14, 26-29]. However, most species of these genus seeds present coat-imposed seed dormancy $[2,30,31]$ which may cause a seed lot to germinate over months or years. Although genetic factors determine the proportion of seed coat hardnesses [10,31], there are several other factors such as the geographical location [32, 33], the earliness of the seeds $[11,15]$, the ecological differences in relation to temperature and relative humidity $[32,34-36]$, and seed storage conditions $[37,38]$.

Previous reports indicated that genotypes and cultivars of Lupinus and Trifolium species have similar seed coat dormancy $[22,39,40]$. Studies on Lupinus species showed that mechanical or chemical scarification is needed to obtain uniform and rapid germination and hot water or boiling treatments can improve germination [22]. Although scarifying seeds of $L$. varius in sulfuric acid were found as alternative to mechanical scarification [22], boiling and scarifying in concentrated sulfuric acid did not provide sufficient germination [41], suggesting that mechanical scarification was the most adequate treatment to obtain uniform and rapid germination.

It was previously reported that ultralow temperature $\left(-196^{\circ} \mathrm{C}\right)$ exposure in liquid nitrogen enhanced final germination and germination speed in seeds of Medicago orbicularis while it did not improve germination parameters of Astragalus hamosus seeds [42]. In addition to mechanical or chemical scarification, storage of Persian clover seeds 
in deep freezer at $-5^{\circ} \mathrm{C}$ for 15 days significantly improved the germination ratios of seeds in different colours [43]. Asci et al. [16] also reported that mechanical scarification was the most effective method to remove the hardness of red clover seeds relative to other methods tested, including precooling, preheating, hot water, and potassium nitrate [16]. The importance of the mechanical scarifying technique, however, lies not just in the possibility that it improves the germinability of seed, but also in how much it can accelerate the process and how practically it can be applied. In addition, mechanical scarification may damage other parts of the seed, including the embryo, and may reduce seed viability due to the pathogenic and saprophytic organisms to gain entry into the seed and thus reduce the shelf life of the seeds although intention of this technique is to provide a minor damage on seed coat for water permeability $[44,45]$. Acid scarification, on the other hand, is commonly not preferred due to its cost, safety risk and environmental precautions involved, and not reliable or lacking the requisite qualities on seeds of other important plant species $[43,44,46]$. Therefore, such precautions have great importance whether or not the technique becomes operationally applicable in large seed lots of various plant species. In agreement with previous reports [46], treatment of white lupin or red clover seeds with HW per se significantly improved FGPs even though the beneficial effects of these treatments were limited in comparison to F1 $+\mathrm{HW}$ method (Figures 1 and 2). The effectiveness of F1 + HW method can also be judged by the high percentage of germinations resulting in white lupin $(84.16 \%)$ and red clover (74.50\%) seeds while UT control seeds had FGPs of 3.3\% and $26.0 \%$, respectively. In addition, germination improvement of red clover seed with F1 + HW method was found to be higher than that of mechanical scarification reported previously [16].

Freeze-thaw scarification method has been known and been used to improve germination of hard seeds in several legume species for a long time [47-51]. Midgley [47] reported that germination of alfalfa seeds was not improved when the seeds were subjected to freeze-thaw scarification with cooling temperatures at $-5^{\circ} \mathrm{C}$ or at $-15^{\circ} \mathrm{C}$ for $36 \mathrm{~h}$ and with warming at room temperatures for six days. Similarly, freezethaw scarification of milk vetch seeds at $-22^{\circ} \mathrm{C}$ for $2,4,7$, $30,60,90$, or 180 days did not improve seed germination more than 78\% [50]. Both Stout [48] and Busse [49] suggested that repeated freeze-thaw cycles were needed to improve germination of alfalfa seeds, although Rutar et al. [51] found no influence on germination of alfalfa seeds when they used the same seed treatments as the study of Stout [48]. Freezethaw scarification using liquid nitrogen was also previously tested and showed no effect on hard seeds of several legume species including alfalfa, red clover, soybean, common vetch [52], and white lupin. Taken together, the results of this study revealed that thawing temperatures or conditions in a freeze-thaw scarification technique would be more critical than freezing temperatures, and immediate or rapid thawing like in hot water would be more beneficial to remove coatimposed seed dormancy in legume plants.

It has been suggested that cracks in the seed coat produced by heat treatment result from seed coat expansion and contraction due to the increase of room temperature to $-80^{\circ} \mathrm{C}$ (hot water) $[23,53]$ while cracks in acid-scarified seeds may be attributed to chemical erosion. The F1 + HW method provides cracks on seed coat and results may be attributed to seed coat expansion or contraction due to the heat shocked on testa of frozen seed. Depending on the species, seed coat thickness, and the size of the seeds used, it is even possible to hear a hatch sound when the seeds were immersed in HW following storage in a deep freezer. As indicated before, storage of white lupin seeds at $-20^{\circ} \mathrm{C}$ for a period of time or immersing the seeds in liquid nitrogen was not sufficient to meet a need for practical application suggesting that combining freezing temperature with $\mathrm{HW}$ at given conditions provided a surface stress on seed coat which can easily be broken and made seeds permeable to water. Previous reports indicated that lens or hilum sides of the testa are the physically weakest part and thus can more easily be broken by treatments $[6,23,53]$. We speculate that the F1+ HW method may also provide cracks on lens or hilum sides of the testa on white lupin and red clover seeds.

In conclusion, we developed a novel and reliable combination of freeze-thaw scarification method $(\mathrm{F} 1+\mathrm{HW})$ which is apparently the quickest and simplest method available for releasing coat-imposed seed dormancy of white lupin and red clover seeds and has a great potential in other plant species in operational applications if the coat-imposed seed dormancy is due to either the impermeability of the coat to water or the mechanical prevention of radicle extension.

\section{Conflict of Interests}

The authors declare that there is no conflict of interests regarding the publication of this paper.

\section{Acknowledgments}

The authors would like to thank Dr. Adem Erol for his help in collecting L. albus seeds and Dr. Ozlem Onal Asci for kindly providing $T$. pratense seeds.

\section{References}

[1] M. Koornneef, L. Bentsink, and H. Hilhorst, "Seed dormancy and germination," Current Opinion in Plant Biology, vol. 5, no. 1, pp. 33-36, 2002.

[2] J. M. Baskin and C. C. Baskin, "A classification system for seed dormancy," Seed Science Research, vol. 14, no. 1, pp. 1-16, 2004.

[3] R. Finkelstein, W. Reeves, T. Ariizumi, and C. Steber, "Molecular aspects of seed dormancy," Annual Review of Plant Biology, vol. 59, pp. 387-415, 2008.

[4] E. Copete, J. M. Herranz, P. Ferrandis, C. C. Baskin, and J. M. Baskin, "Physiology, morphology and phenology of seed dormancy break and germination in the endemic Iberian species Narcissus hispanicus (Amaryllidaceae)," Annals of Botany, vol. 107, no. 6, pp. 1003-1016, 2011.

[5] K. M. Kelly, J. van Staden, and W. E. Bell, "Seed coat structure and dormancy," Plant Growth Regulation, vol. 11, no. 3, pp. 201209, 1992. 
[6] J. M. Baskin, C. C. Baskin, and X. J. Li, "Taxonomy, anatomy and evolution of physical dormancy in seeds," Plant Species Biology, vol. 15 , no. 2, pp. 139-152, 2000.

[7] G. Ladizinsky, "The genetics of hard seed coat in the genus Lens," Euphytica, vol. 34, no. 2, pp. 539-543, 1985.

[8] H. Weber, L. Borisjuk, and U. Wobus, "Controlling seed development and seed size in Vicia faba: a role for seed coatassociated invertases and carbohydrate state," Plant Journal, vol. 10, no. 5, pp. 823-834, 1996.

[9] P. M. Erdmann, R. K. Lee, M. J. Bassett, and P. E. McClean, "A molecular marker tightly linked to $\mathrm{P}$, a gene required for flower and seedcoat color in common bean (Phaseolus vulgaris L.), contains the Ty3-gypsy retrotransposon Tpv3g," Genome, vol. 45, no. 4, pp. 728-736, 2002.

[10] C. Tinius, "Variable expression of seed coat permeability," Soybean Genetics Newsletter, vol. 18, pp. 256-259, 1991.

[11] K. Ranathunge, S. Shao, D. Qutob, M. Gijzen, C. A. Peterson, and M. A. Bernards, "Properties of the soybean seed coat cuticle change during development," Planta, vol. 231, no. 5, pp. 1171$1188,2010$.

[12] W. M. Lush and L. T. Evans, "The seed coats of cowpeas and other grain legumes: structure in relation to function," Field Crops Research, vol. 3, pp. 267-286, 1980.

[13] H. N. Büyükkartal, H. Çölgeçen, N. M. Pinar, and N. Erdoǧan, "Seed coat ultrastructure of hard-seeded and soft-seeded varieties of Vicia sativa," Turkish Journal of Botany, vol. 37, no. 2, pp. 270-275, 2013.

[14] E. Can, N. Çeliktaş, R. Hatipoğlu, and S. Avci, "Breaking seed dormancy of some annual Medicago and Trifolium species by different treatments," Turkish Journal of Field Crops, vol. 14, no. 2, pp. 72-78, 2009.

[15] F. R. Hay, R. D. Smith, R. H. Ellis, and L. H. Butler, "Developmental changes in the germinability, desiccation tolerance, hardseededness, and longevity of individual seeds of Trifolium ambiguum," Annals of Botany, vol. 105, no. 6, pp. 1035-1052, 2010.

[16] O. O. Asci, Z. Acar, I. Ayan, U. Basaran, and H. Mut, "Effect of pretreatments on seed germination rate of red clover (Trifolium pratense L.) populations," African Journal of Agricultural Research, vol. 6, no. 13, pp. 3055-3060, 2011.

[17] A. Meisert, D. Schulz, and H. Lehmann, "Structural features underlying hardseededness in geraniaceae," Plant Biology, vol. 1, no. 3, pp. 311-314, 1999.

[18] I. A. Takos and G. S. P. Efthimiou, "Germination results on dormant seeds of fifteen tree species autumn sown in a Northern Greek nursery," Silvae Genetica, vol. 52, no. 2, pp. 6771, 2003.

[19] M. M. A. El Balla, A. I. Saidahmed, and M. Makkawi, "Effect of moisture content and maturity on hardseededness and germination in okra (Abelmoschus esculentus L. Moench)," International Journal of Plant Physiology and Biochemistry, vol. 3, pp. 102-107, 2011.

[20] J. D. Bewley, "Seed germination and dormancy," Plant Cell, vol. 9, no. 7, pp. 1055-1066, 1997.

[21] R. M. Nair, A. D. Craig, T. D. Rowe, S. R. Biggins, and C. H. Hunt, "Genetic variability and heritability estimates for hardseededness and flowering in balansa clover (Trifolium michelianum Savi) populations," Euphytica, vol. 138, no. 3, pp. 197-203, 2004.

[22] O. Karaguzel, S. Cakmakci, V. Ortacesme, and B. Aydinoglu, "Influence of seed coat treatments on germination and early seedling growth of Lupinus varius L.," Pakistan Journal of Botany, vol. 36, no. 1, pp. 65-74, 2004.

[23] X. W. Hu, Y. R. Wang, Y. P. Wu, and C. C. Baskin, "Role of the lens in controlling water uptake in seeds of two Fabaceae (Papilionoideae) species treated with sulphuric acid and hot water," Seed Science Research, vol. 19, no. 2, pp. 73-80, 2009.

[24] S. R. Wiley, R. J. Kraus, F. Zuo, E. E. Murray, K. Loritz, and J. E. Mertz, "SV40 early-to-late switch involves titration of cellular transcriptional repressors," Genes and Development, vol. 7, no. 11, pp. 2206-2219, 1993.

[25] SAS I, SAS/STAT Software: Changes and Enhancements through Release 6.12, SAS Inst., Cary, NC, USA, 1997.

[26] M. J. Messina, "Legumes and soybeans: Overview of their nutritional profiles and health effects," The American Journal of Clinical Nutrition, vol. 70, no. 3, 1999.

[27] M. Carbonaro, G. Grant, M. Mattera, A. Aguzzi, and A. Pusztai, "Investigation of the mechanisms affecting $\mathrm{Cu}$ and $\mathrm{Fe}$ bioavailability from legumes: role of seed protein and antinutritional (nonprotein) factors," Biological Trace Element Research, vol. 84, no. 1-3, pp. 181-196, 2001.

[28] D. M. Roth and B. R. Paulicks, "Contents of nutrients and feed value of blue and yellow lupins (Lupinus angustifolius L., Lupinus luteus L.) for pigs," Proceedings of the Society of Nutrition Physiology, vol. 11, p. 137, 2002.

[29] L. W. Bell, M. H. Ryan, R. G. Bennett, M. T. Collins, and H. J. Clarke, "Growth, yield and seed composition of native Australian legumes with potential as grain crops," Journal of the Science of Food and Agriculture, vol. 92, no. 7, pp. 1354-1361, 2012.

[30] C. C. Baskin and J. M. Baskin, "Ecology and evolution of specialized seed dispersal, dormancy and germination strategies," Plant Species Biology, vol. 15, no. 2, pp. 95-96, 2000.

[31] J. A. Van Assche and F. E. A. Vandelook, "Combinational dormancy in winter annual Fabaceae," Seed Science Research, vol. 20, no. 4, pp. 237-242, 2010.

[32] P. J. Argel and L. R. Humphreys, "Environmental effects on seed development and hardseededness in Stylosanthes hamata cv. Verano. I. Temperature," Australian Journal of Agricultural Research, vol. 34, no. 3, pp. 261-270, 1983.

[33] F. H. Dübbern De Souza and J. Marhos-Filho, "The seed coat as a modulator of seed-environment relationships in Fabeceae," Revista Brasileira de Botanica, vol. 24, pp. 365-375, 2001.

[34] J. J. Mott, S. J. Cook, and R. J. Williams, "Influence of short duration, high temperature seed treatment on the germination of some tropical and temperate legumes," Tropical Grasslands, vol. 16, pp. 50-55, 1982.

[35] H. C. Norman, P. S. Cocks, and N. W. Galwey, "Hardseededness in annual clovers: variation between populations from wet and dry environments," Australian Journal of Agricultural Research, vol. 53, no. 7, pp. 821-829, 2002.

[36] A. Balkaya, "Modelling the effect of temperature on the germination speed in some legume crops," Journal of Agricultural, vol. 3, pp. 179-183, 2004.

[37] R. L. Benech-Arnold, R. A. Sánchez, F. Forcella, B. C. Kruk, and C. M. Ghersa, "Environmental control of dormancy in weed seed banks in soil," Field Crops Research, vol. 67, no. 2, pp. 105$122,2000$.

[38] K. M. G. Gehan Jayasuriya, J. M. Baskin, C. C. Baskin, and M. T. R. Fernando, "Variation in seed dormancy and storage behavior of three liana species of derris (Fabaceae, Faboideae) in Sri Lanka and ecological implications," Research Journal of Seed Science, vol. 5, no. 1, pp. 1-18, 2012. 
[39] G. S. Valenti, L. Melone, M. Ferro, and A. Bozzini, "Comparative studies on testa structure of "hard-seeded" and "soft-seeded" varieties of Lupinus angustifolius L. (Leguminosae) and on mechanism of water entry," Seed Science and Technology, vol. 17, pp. 563-581, 1989.

[40] T. D. Davis, S. W. George, A. Upadhyaya, and J. Parsons, "Improvement of seedling emergence of Lupinus taxensis Hook. following seed scarification treatments," Journal of Environmental Horticulture, vol. 9, pp. 17-21, 1991.

[41] O. Karaguzel, I. Baktir, S. Cakmakci, V. Ortacesme, B. Aydinoglu, and M. Atik, "Effects of scarification methods, temperature and sowing date on some germination characteristics of Lupinus varius L.," in Proceedings of the 2nd National Congress on Ornamental Plants, pp. 40-47, Citrus and Greenhouse Research Institute, Antalya, Turkey, October 2002.

[42] C. Patanè and F. Gresta, "Germination of Astragalus hamosus and Medicago orbicularis as affected by seed-coat dormancy breaking techniques," Journal of Arid Environments, vol. 67, no. 1, pp. 165-173, 2006.

[43] E. Ates, "Influence of some hardseededness-breaking treatments on germination in Persian clover (trifolium resupinatum ssp. typicum Fiori et Paol.) seeds," Romanian Agricultural Research, no. 28, pp. 229-236, 2011.

[44] DS. Loch and GL. Harvey, "Comparison of methods for reducing hard seed levels in three subtropical legumes," in Proceedings of the 4th Australian Seeds Research Conference, pp. 243-246, Broadbeach, Australia, 1992.

[45] S. N. Acharya, D. G. Stout, B. Brooke, and D. Thompson, "Cultivar and storage effects on germination and hard seed content of alfalfa," Canadian Journal of Plant Science, vol. 79, no. 2, pp. 201-208, 1999.

[46] A. Alderete-Chavez, L. Aguilar-Marín, N. de la cruz-Landero et al., "Effects of scarification chemical treatments on the germination of Crotalaria retusa L. seeds," Journal of Biological Sciences, vol. 10, no. 6, pp. 541-544, 2010.

[47] A. R. Midgley, "Effect of alternate freezing and thawing on the impermeability of alfalfa and dodder seeds," Journal of the American Society of Agronomy, vol. 18, pp. 1087-1098, 1926.

[48] D. G. Stout, "Effect of freeze-thaw cycles on hard-seededness of alfalfa," Journal of Seed Science and Technology, vol. 14, pp. 47$55,1990$.

[49] W. F. Busse, "Effect of low temperatures on germination of impermeable seeds," Botanical Gazette, vol. 89, pp. 169-179, 1930.

[50] T. Shibata and Y. Hatakeyama, "Breaking of dormancy in the seeds of Astragalus mongholicus Bunge (Leguminosae)," Journal of Plant Physiology, vol. 146, no. 3, pp. 366-368, 1995.

[51] R. Rutar, M. Stjepanovic, S. Popovic, Z. Bukvic, and D. Pacek, "Effect of temperature on germination and hard alfalfa seed," CIHEAM, vol. 2, pp. 137-139, 2001.

[52] P. C. Stanwood, "Tolerance of crop seeds to cooling and storage in liquid nitrogen $\left(-196^{\circ} \mathrm{C}\right)$," Journal of Seed Technology, vol. 5, no. 1, pp. 26-31, 1980.

[53] L. W. Zeng, P. S. Cocks, S. G. Kailis, and J. Kuo, "The role of fractures and lipids in the seed coat in the loss of hardseededness of six Mediterranean legume species," Journal of Agricultural Science, vol. 143, no. 1, pp. 43-55, 2005. 

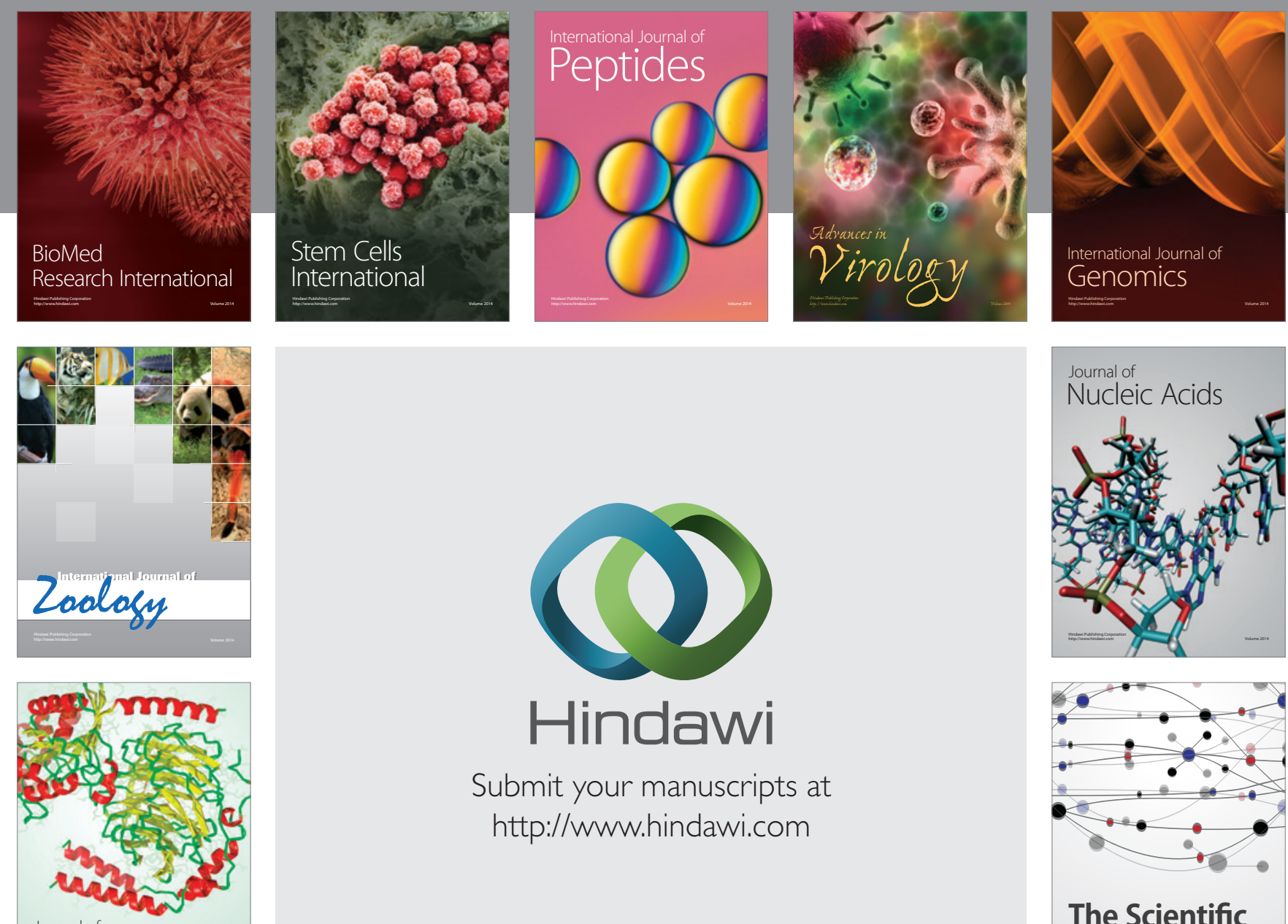

Submit your manuscripts at

http://www.hindawi.com

Journal of
Signal Transduction
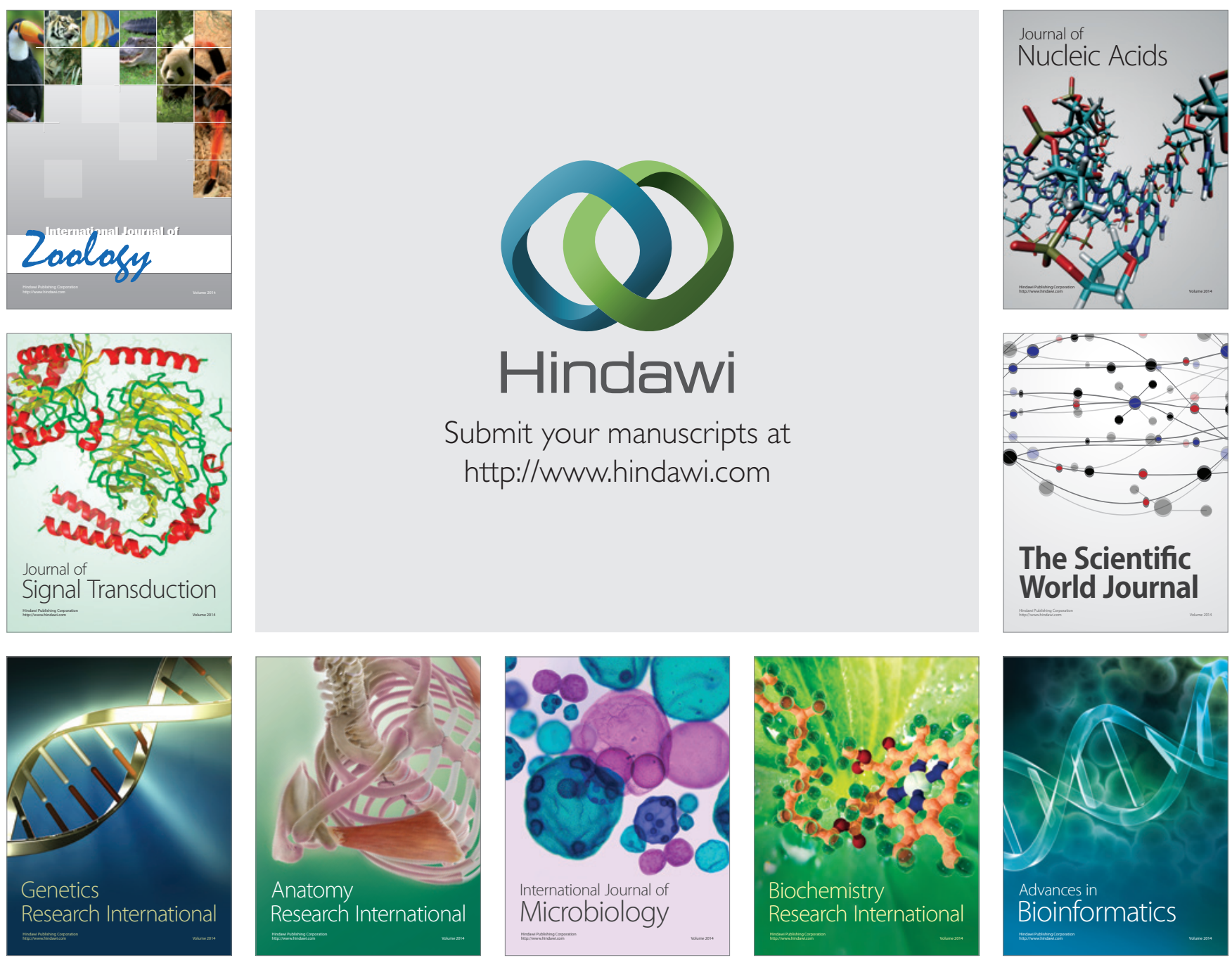

The Scientific World Journal
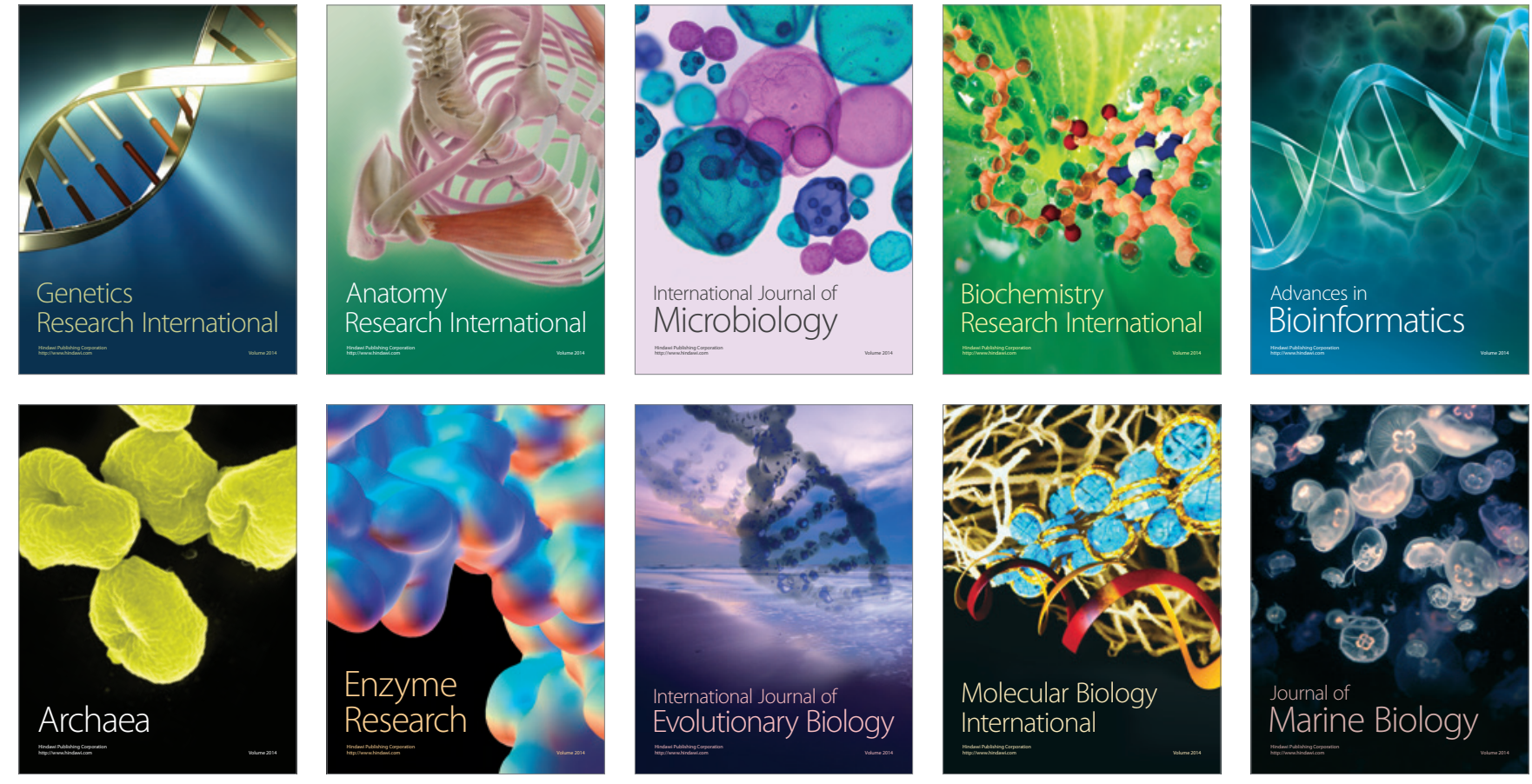